\title{
NOVICE INVESTOR BEHAVIORIN INDONESIA STOCK EXCHANGE: A COMPARATIVE STUDY BEFORE AND DURING COVID-19 PANDEMIC
}

\author{
Eko Ganiarto ${ }^{1}$, Farida Komalasari ${ }^{2}$ and Lucia Elshadai Lastria Monita Manik ${ }^{3}$ \\ ${ }^{1}$ Management Study Programme, Faculty of Business, President University \\ ${ }^{2}$ Business Administration Study Programme, Faculty of Business, President University \\ ${ }^{3}$ Business Administration Study Programme, Faculty of Business, President University \\ leganiarto@president.ac.id,2farida_k@president.ac.id and ${ }^{3}$ elshadaimanik05@gmail.com
}

\begin{abstract}
Abstrak
Investor pemula mempunyai peran penting dalam perekonomian Indonesia. Jumlah investor pemula menunjukkan peningkatan yang signifikan. Mempelajari perilaku para investor pemula merupakan hal yang menarik, mengingat segala aktivitas mereka pada akhirnya akan mempengaruhi investasi dan perekonomian secara keseluruhan. Tujuan studi ini adalah menentukan faktor-faktor yang memengaruhi perilaku investasi para investor pemula dan melihat apakah ada perbedaan perilaku berinvestasi para investor pemula antara sebelum Pandemi Covid-19 dan selama Pandemi Covid-19.Studi ini merupakan penelitian kuantitatif, yang mengimplementasikan teori perilaku terencana (the theory of planned behavior) dengan mewawancarai 234 investor pemula di Bursa Efek Indonesiasebagai respondenyang dipilih dengan metode purposive sampling. Variabel yang digunakan meliputisikap investor terhadap investasi (attitude toward investment), norma subjektif dalam berinvestasi (subjective norm in investing), dan persepsi pengendalian perilaku dalam berinvestasi (perceived behavioral control in investing) sebagai variabel independen. Sementara niat berinvestasi (investing intention) dan perilaku berinvestasi (investing behavior) sebagai variabel dependen. Data diolah dan dianalisis dengan menggunakan modelStuctural Equation Modelling (SEM). Hasil studi menunjukkan bahwa pada masa Pandemi Covid-19, sikap investor, norma subjektif, dan persepsi pengendalian perilaku, berpengaruh pada niat berinvestasi investor pemula. Sementara pada saat sebelum Pandemi Covid-19, norma subyektif tidak berpengaruh pada niat berinvestasi. Selanjutnya, pada kedua periode tersebut, niat berinvestasi memengaruhi perilaku berinvestasi investor pemula.
\end{abstract}

Kata kunci:investor pemula, teori perilaku terencana, niat berinvestasi, perilaku berinvestasi, Bursa Efek Indonesia.

\begin{abstract}
Novice investorshave an important role in the Indonesian economy. The number of novice investor increased significantly. It is interesting to study the behavior of novice investors, considering that all their activities will ultimately affect investment and the economy as a whole. The purpose of this study is to determine what factors influence the investing behavior of novice investors and to see if there are any differences in the investing behavior of novice investors, before the Covid-19 Pandemic and during the Covid-19 Pandemic. This study is a quantitative study, that implements the planned behavior theory which interviewed 234 novice investors in Indonesia Stocks Exchange as respondents, who were selected using purposive sampling method. The variables used includeattitude toward investment, subjective norms in investing, and perceived behavioral control in investing as independent variables. While investing intention and investing behavior as dependent variables. The data is processed and analyzed using Structural Equation Modelling (SEM) method. The results show that during the Covid-19 Pandemic, investor attitudes, subjective norms, and perceived behavioral control influenced investing intention of novice investors. While prior to the Covid-19 Pandemic, subjective norm did not influence on investing intention. Furthermore, in both periodsinvesting intention influenced investing behavior of novice investors.
\end{abstract}

Keywords: noviceinvestor, the theory of palnned behavior, investing intention, investing behavior, Indonesia Stocks Exchange. 


\section{A. Introduction}

Investors have a very important role in driving the economy of a country. One indicator of a country's economic progress can be seen from the number of investors involved in its economy. Harrod (1939) and Domar (1947) stated in their theory that investment activities have a good effect on a country's economic growth. The more investment activities carried out, the higher the income generated by the state. On the other hand, investment can increase the production capacity of the economy by increasing the capital stock (Aristanti, 2020).

One of the attractive investment places for investors is a capital market. The more investors who are active in the capital market, the more capital is available in the economy. Therefore, the large number of investors who are active in the capital market is an important indicator of an economy development. In this case, the investors referred to are not only corporate investors but also retail investors, including novice investors.

In an effort to increase the number of investors in Indonesia, especially domestic investors, the Indonesian government has made various regulations/policies and movements that encourage the birth of new investors (beginners). The policy referred to, among others, is the change in the share trading unit from 1 lot containing 500 shares to 100 shares. The regulation issued in 2013 is intended to make the capital market more affordable to the public, especially retail investors (beginners) who have limited capital (Agustina, 2013).

In line with that, the Indonesia Stock Exchange in 2015 carried out a "Let's Save Stocks" campaign which aims to encourage people to invest in the capital market by buying shares regularly and periodically. Such regulations and activities will certainly have a positive impact on the development of the capital market in particular and the economy in general (Bursa Efek Indonesia, 2017).

The performance of the Indonesian stock market had slumped due to the Covid-19 pandemic. However, at the same time the number of retail investors in Indonesia has increased significantly, even becoming the masters of stock transactions. Even according to the Director of Development of the Indonesia Stock Exchange, Hasan Fawzi, 2020 is a period of revival of domestic retail investors in the Indonesian capital market. Furthermore, Hasan added, in terms of the growth of SID (single investor identification) new shares, the number has increased by 93.4\%, from 252,370 SID in 2019 to 488,088 new SID shares in 2020 (Sidik, 2020).

The number of stock investors as of December 10, 2020 was 1,592,698 SID or $44.19 \%$ of the total stock investors in the Indonesian capital market. In addition, the dominance of domestic investor ownership in scripless shares has reached the highest in the history of the Indonesian 
capital market. Of the Rp 3.491 trillion total shareholdings listed on the IDX, $50.44 \%$ belong to domestic retail investors, while $49.56 \%$ are owned by foreign investors(Sidik, 2020).

The momentum of domination by domestic retail investors can also be seen from the average daily transaction value of the stock exchange. Data on the average daily transaction value on an annual basis (year to date) from January to November 2020, amounting to Rp. 8.42 trillion, as much as $45.9 \%$ of which was contributed by transaction activities carried out by retail investors and this is the highest in the history of the Indonesian capital market (Sidik, 2020).

Indonesian capital market investors continue to experience an increase. Based on data from the Indonesia Stock Exchange (IDX), the number of investors as of November 19, 2020 has reached 3.53 million, an increase of $42 \%$ compared to the end of 2019. Among them, share investors reached 1.5 million or grew $36.13 \%$ from last year (Hutauruk, 2021).

Specifically for 2020, the number of new investors aged 18 to 25 has increased by 211,030 or $43.23 \%$ of the total new investors and ages 26 to 30 have increased 96.396 or $19.74 \%$ of the total new investors. Furthermore, the wave of stock retail investors dominated by milleninals is a reward for the development of the Indonesian capital market. With the entry of retail investors, the liquidity of the stock market in the capital market has increased significantly to make a new history, which makes stock market liquidity better in the eyes of global investors. However, this increase in the number of investors was not followed by the number of good stock analysts, so that it could lead to an instant rich perspective through stocks with high expectations, especially among novice investors (young people) (Olavia, 2021).

Given that new investors (beginners) will increase in the future, not only in terms of quantity, but also in quality, it is important to study their behavior. How have they behaved in investing, both before and during the Covid-19 Pandemic? What factors influence their behavior? These questions will be answered through this study.

The aims of this study are:

1. To know the factors that influence the behavioral intention in investing of novice investor.

2. To know the influence of behavioral intention to actual behavior in investing of novice investor.

3. To know whether any difference behavior in investing of novice investor, before and during Covid-19 Pandemic. 


\section{B. Theoritical Review}

\section{The Theory of Planned Behavior}

This study implements the theory of planned behavior (TPB) proposed by Ajzen (1988). This theory is a development of the theory of reasoned action (TRA) proposed by Ajzen \&Fishbein (1980). In TRA, a person who performs an action (behaves) is determined by his intention to do that action. Meanwhile, the intention to do something is caused by two factors, namely attitudes towards behavior and subjective norms.In 1988, Ajzen added one more factor that influences behavioral intention (third factor), namely perceived behavioral control, complementing the two previous factors. The existence of this third factor then changes TRA into TPB. Based on TPB, there were three factors that influenced the intention behavior. They were attitudes toward behavior, subjective norm and perceived behavioral control. Then the intention to behave will affect a person's actual behavior. This theory also stated that person's behavior could be influenced directly by perceived behavioral control (Ajzen, 1991).

This study implements the TPB in investment behavior. Therefore, the five variables of TPB used in this study were changed into attitude towardinvestment, subjective norm in investing, perceived behavioral control in investing, investing intention, and investing behavior. The explanation of each variableis provided as follow.

\section{Attitude toward Investment}

Ajzen in Mahyarni (2013) states that attitudes towards behavior is determined by behavioral beliefs. Belief deals with a person's subjective assessments of the world around him, an understanding of himself and his environment. Belief can be identified by connecting predictions of a behavior with the benefits or losses that might be obtained if the behavior is done or not carried out. This belief can strengthen attitudes towards behavior based on the evaluation results that the behavior can provide benefits for the perpetrator.

Attitude can be identified as an outcome assessment related to a particular behavior and is supported by previous experience. The factors that arise from individuals have a positive influence in forming the type of attitude which then triggers certain behaviors (Kashif, Zarkada, \& Ramayah, 2018).

In relation to investment, attitude toward investment refers to the extent to which a person has thoughts or evaluations about interesting behavior given whether it is beneficial or not (Raut \& Das, 2017). Based on the study conducted by Foltz, Newkirk, \&Schwager (2017), 
investor's attitude in investing can be changed either positive or negative depend on the current situation. A person's attitude can change depending on the current situation, for example when a recession occurs, a person's attitude can become more conservative before taking action (Dow, 2018).

Attitude can be measured by factors of good idea, wise choice, idea, interest and involvement in investment activities (Raut \& Das, 2017; Palamida, Papagiannidis, \& Xanthopoulou, 2017).

\section{Subjective Norm in Investing}

Subjective norm is a person's feelings or guesses about the expectations of the people in his life about being done or not behaving in a certain way(Ajzen in Mahyarni, 2013).

In relation to investment, subjective norm in investing is part of the external factor of the individual investor because it arises from the other investors' perception about the behavior whether it approved or not to be performed (Baron\&Byrne in Taufiqoh, Nur, \& Junaidi, 2019). Subjective norm formed by suggestions or recommendations from fellow investors that can influence other investors in making investment decisions (Paramita, Isbanah, Kusumaningrum, Musdholifah, \& Hartono, 2018).

\section{Perceived Behavioral Control in Investing}

Perceived of behavior control or also known as behavior control is a person's feelings about the ease or difficulty of realizing a certain behavior (Ajzen, 2005 in Mahyarni, 2013). Furthermore, Ajzen explained the feelings related to control behavior by distinguishing them from Rotter's locus of control or control center. The control center is concerned with a person's belief that is relatively stable in all situations. Perceived behavioral control can change depending on the situation and the type of behavior to be performed. The control center is related to an individual's belief that his success in doing everything depends on his efforts (Rotter's, 1966 in Mahyarni, 2013).

Perceived behavioral control is the investors' belief about how convenient or complicated and how much confidence the investors can affect their own thinking to control their behavior to do investment (Paramita, et. al., 2018). According to Ibrahim \&Arshad (2017), perceived behavioral control can be referred to as the investors' ability to control their performance over the particular behavior related to the investment context. If the current condition is positive, the perception of perceived behavioral control will be stronger to do a particular behavior. But if the 
current condition is negative like Covid-19 Pandemic, the individual's perception about their abilities to take a certain behavior will be negative too (Ruiz-Rosa, Guttierrez-Tano, \& GarciaRodriguez, 2020).

\section{Investing Intention}

Ajzen in Seni\& Ratnadi (2017) defined intention as an arrangement of actions which, if there is a suitable time and opportunity, it will be realized in the form of action. Intention was the central factor in the planned behavior theory, since the person's was preceded by person's intention.According to Peter \&Olson as cited in Paramita, et al. (2018), behavioral intention is the level of an individual indication that is willing to try their plan and apply in an effort to show behavior.

In this study, investing intention is defined as the degree and tendency of the investor to keep doing investment. Behavioral intention has been confirmed as the most determinant of investor behavior over the investment activities (Venkatesh,, et al. (2003) and Venkatesh et al. (2012) in Alalwan, Dwivedi, \& Rana, 2016),

\section{Investing Behavior}

Fishbein \& Ajzen as cited by Raut \&Das (2017), stated that actual behavior can be defined as the manifestation of the thought and observation to which an individual performs or reject perform that is obtained.

According to Belch \& Belch as cited in Trang \& Tho (2017), actual behavior refers to the process and activities when individuals are searching, purchasing, using, and evaluating of the particular products or services.

In the context of investing, actual behavior or investing behavior can be defined as the result of the investors' evaluation after through the planning process to take investment decision (Paramita, et.al., 2018). Meanwhile, Lintner as cited in Yuniningsih \&Taufiq (2019), defined actual behavior as how the investors interpret and perform their behavior based on the information and their control to execute in investment activities. Actual behavior in investment can be changed because of the individual perception of the investment when a certain condition, for example when the financial crisis 2008-2009 happened. The individual's perception became fluctuates during the financial crisis (Hoffmann, Post, \& Pennings, 2013).

\section{Theoretical Framework}


This study uses a theoretical framework based on the behavior planned theory which can be seen in Figure 1.

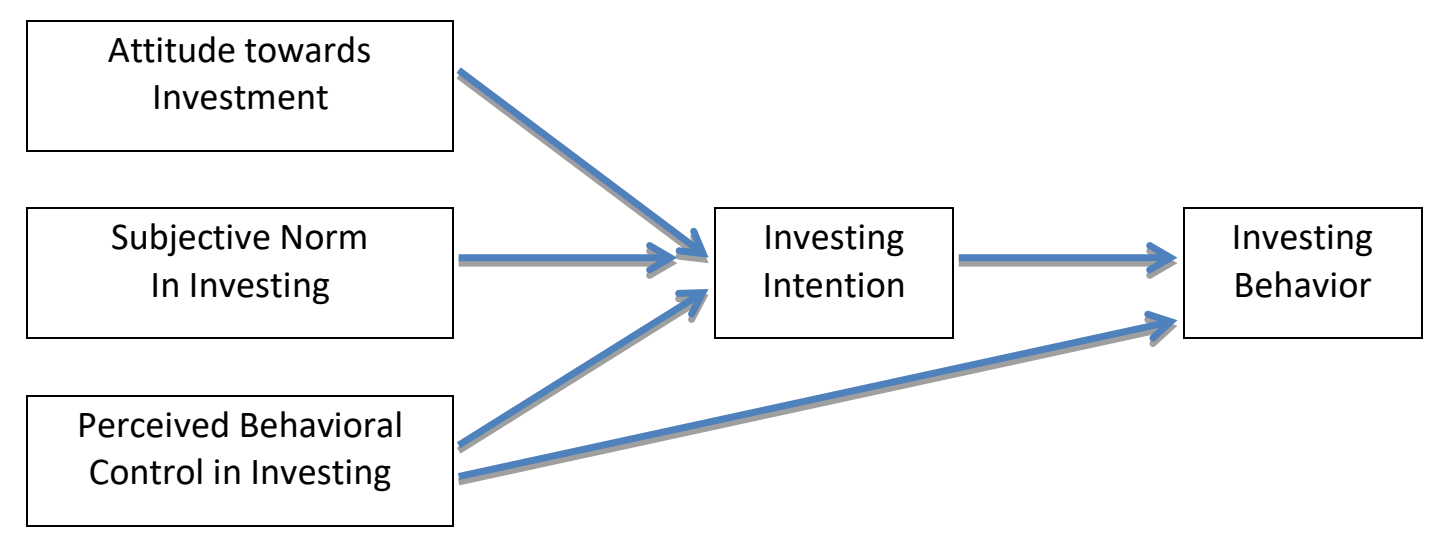

Source: Modifoed from Ajzen (1991)

Figure 1. Theoretical Framework

\section{The Hypotheses}

Based on the description of the theory and the theoretical framework depicted in Figure 1, the following hypotheses can be formulated:

1. $\mathrm{H}_{1}$ : Attitude toward investment influences investingintention

2. $\mathrm{H}_{2}$ : Subjective norms in investing influences investing intention

3. $\mathrm{H}_{3}$ : Perceived behavioral control in investing influences investing intention

4. $\mathrm{H}_{4}$ : Investing intention influences investing behavior

5. $\mathrm{H}_{5}$ : Perceived behavioral control in investing influences investing behavior directly

\section{Research Method}

This study used quantitative approach by using primary data. The data were collected from 234 respondents who are novice investors. The population are the novice investors in Indonesia Stock Exchange. A novice investor is an investor who has just started stock investment activities in the last three years. The respondents are chosen by using non-probability sampling, which is purposive sampling.

To gather the data, the questionnaires were distributed to respondent through Google Form in period August - September 2020, when the Covid-19 Pandemic has been happened in Indonesia since March 2020. The questionnaire consists of three sections. Those are screening question, respondent's profile, and variable's measurement. The screening question is used to 
make sure that the respondent is part of the population. The respondents' profiles is needed to describe the characteristic of respondents, that cover gender, age, education, occupation, and income. The respondents were asked their behavior when they invest in stock exchange, both before and during Covid-19 Pandemic by using the same questions.

This studyused five main variables (latent variables/construct). They are attitudes toward investment (AT), subjective norms in investing ( $\mathrm{SN})$, perceived behavioral control of investing $(\mathrm{PB})$, investing intention (BI) and investing behavior $(\mathrm{AB})$. Each latent variable/construct is measured using five indicators/measurable variables in the form of statements which its answers using an interval scale, with a value between 1 (strongly disagree) and 7 (strongly agree).

The data are analyzed by using Structural Equation Modeling (SEM) method for inferential analyisis, using statistical software. The steps are as follow (Santoso, 2012; Ghozali, 2013):

1. Testing the data validity by correlation analysis for total and each variable. See the output of correlation analysis, the data considered to be valid if the significant value was less than 0.05 .

2. Testing the data reliability by reliability analysis. See the output of reliability analysis, the data considered to be reliable if the value of Cronbach's Alpha was more than 0.6.

3. Testing the data normality by using One-Sample Kolmogorov-Smirnov Test. See the output table and find the significant value of standardized residual (Monte Carlo Method), the data considered to be normal if the significant value of standardized residual was more than 0.05 .

4. Testing the goodness of fit for both period, before Covid-19 Pandemic and during Covid-19 Pandemic. See some outputs of SEM analysis especially for testing the goodness of fit asprovided on Table 1.

Table 1. The Suggested Value of Goodness of Fit Test Result

\begin{tabular}{|c|l|c|}
\hline No. & \multicolumn{1}{|c|}{ Goodness of Fit Indicators } & $\begin{array}{c}\text { Suggested } \\
\text { Value }\end{array}$ \\
\hline 1. & CMIN/DF & $\leq 5$ \\
\hline 2. & GFI (Goodness of Fit Index) & $\geq 0.90$ \\
\hline 3. & $\begin{array}{l}\text { RMSEA (Root Mean Square Error of } \\
\text { Approximation) }\end{array}$ & $0.05-0.08$ \\
\hline 4. & CFI (Comparative Fit Index) & $\geq 0.90$ \\
\hline 5. & TLI (Tucker Lewis Index) & $\geq 0.90$ \\
\hline 6. & PNFI (Parsimonious Normal Fit Index) & $0.60-0.90$ \\
\hline
\end{tabular}


5. Testing the hypotheses by using SEM Analysis. See the output of regression analysis for both period, before Covid-19 Pandemic and during Covid-19 Pandemic, especially in regression weight table:

a. If the significant value of Attitude (AT)was less than 0.05 then attitude toward investment influenced investing intention

b. If the significant value of subjective norms in investing ( $\mathrm{SN}$ )was less than 0.05 then subjective norms in investing influencedinvesting intention

c. If the significant value of perceived behavioral control of investing (PB) was less than 0.05 then perceived behavioral control of investinginfluencedinvesting intention

d. If the significant value of investing intention (BI) was less than 0.05 then investing intention influencedinvesting behavior

e. If the significant value of perceived behavioral control of investing (PB) was less than 0.05 then perceived behavioral control of investinginfluencedinvesting behavior

\section{Results and Discussion}

\section{Respondents' Profile}

Respondents in this study were mostly male (64.5\%), of which $54 \%$ were between $21-25$ years old. Meanwhile, for female respondents, there are 45\% who are between 21-25 years old. When viewed based on the latest education, $50 \%$ of the respondents have a bachelor degree (S1) and $38.5 \%$ have a senior high/vocational school education. In terms of work, $46.2 \%$ of respondents are still in school/college, $44.4 \%$ as employees, $6 \%$ as entrepreneurs and $3.4 \%$ other workers. Meanwhile, if viewed from the perspective of monthly income, $35 \%$ of the respondents have an income of less than IDR 3,500,000/month. This is understandable, considering that almost $90 \%$ of them are students, who have an allowance - not income - per month of less than IDR 3,500,000. Meanwhile, there are 34.7\% of respondents who earn between Rp 3,500,000 Rp 6,500,000 and 30.3\% others who earn more than Rp. 6,500,000/month.

\section{Validity and Reliability Test}

Based on the validity and reliability analysis, the research data met the requirements, namely reliable and valid. The results of the validity test using Correlation Analysis showed that all variables have a significant value of 0.000 or less than 0.05 , which meant that the data were 
valid. Meanwhile, based on the validity test, the Cronbach's Alpha value was 0.884 which exceeded the value of 0.06 . This means that the data were reliable.

\section{Normality Test}

The collected data is first processed using SPSS software, to check whether the data is normally distributed or not. From 303 collected data, after being examined and analyzed, it turned out that only 234 were suitable for further analysis. The results of the data normality analysis show that the existing data was normally distributed based on the results of the examination using the One-Sample Kolmogorov-Smirnov Test with the Monte Carlo method, which was as follows:

a. the significant value of standardized residual for data before the Covid-19 pandemic was 0.156

b. the significant value of standardized residual for data during the Covid-19 pandemic was 0.358

Because both significant values were greater than 0.05 , the data can be concludedthat the data were normally distributed.

\section{Testing the Goodness of Fit}

Based on data analysis using SEM, the results were on Table 2 and Table 3.

Table 2. Goodness of Fit Test Result - Before Covid-19 Pandemic

\begin{tabular}{|c|l|c|c|c|}
\hline No. & \multicolumn{1}{|c|}{ Goodness of Fit Indicators } & $\begin{array}{c}\text { Result } \\
\text { Value }\end{array}$ & $\begin{array}{c}\text { Suggested } \\
\text { Value }\end{array}$ & Evaluation \\
\hline 1. & CMIN/DF & 1.85 & $\leq 5$ & Good \\
\hline 2. & GFI (Goodness of Fit Index) & 0.91 & $\geq 0.90$ & Good \\
\hline 3. & $\begin{array}{l}\text { RMSEA (Root Mean Square Error of } \\
\text { Approximation) }\end{array}$ & 0.06 & $0.05-0.08$ & Good \\
\hline 4. & CFI (Comparative Fit Index) & 0.96 & $\geq 0.90$ & Good \\
\hline 5. & TLI (Tucker Lewis Index) & 0.94 & $\geq 0.90$ & Good \\
\hline 6. & PNFI (Parsimonious Normal Fit Index) & 0.73 & $0.60-0.90$ & Good \\
\hline
\end{tabular}

Table 3. Goodness of Fit Test Result - During Covid-19 Pandemic

\begin{tabular}{|c|l|c|c|c|}
\hline No. & \multicolumn{1}{|c|}{ Goodness of Fit Indicators } & $\begin{array}{c}\text { Result } \\
\text { Value }\end{array}$ & $\begin{array}{c}\text { Suggested } \\
\text { Value }\end{array}$ & Evaluation \\
\hline 1. & CMIN/DF & 2.642 & $\leq 5$ & Good \\
\hline
\end{tabular}




\begin{tabular}{|c|l|c|c|c|}
\hline 2. & GFI (Goodness of Fit Index) & 0.90 & $\geq 0.90$ & Good \\
\hline 3. & $\begin{array}{l}\text { RMSEA (Root Mean Square Error of } \\
\text { Approximation) }\end{array}$ & 0.08 & $0.05-0.08$ & Good \\
\hline 4. & CFI (Comparative Fit Index) & 0.94 & $\geq 0.90$ & Good \\
\hline 5. & TLI (Tucker Lewis Index) & 0.93 & $\geq 0.90$ & Good \\
\hline 6. & PNFI (Parsimonious Normal Fit Index) & 0.73 & $0.60-0.90$ & Good \\
\hline
\end{tabular}

Table 2 and Table 3 showed the result of the Goodness of Fit test, for the period before the Covid-19 Pandemic and during the Covid-19 Pandemic period.In both period, the Goodness of Fit test were met the requirement as a good model.

\section{Hypothesis testing}

The results of hypothesis testing can be seen in the regression weight table, as seen on Table 4.

Table 4. Regression Weight - Before Covid-19 Pandemic

\begin{tabular}{|c|c|c|c|c|c|}
\hline & Estimate & S.E. & C.R. & $\mathrm{P}$ & Result \\
\hline BI1 <--- AT1 & .676 & .116 & 5.842 & $* * *$ & $\mathrm{H}_{1}$ is accepted \\
\hline BI1 <--- SN1 & .015 & .037 & .394 & .693 & $\mathrm{H}_{2}$ is rejected \\
\hline BI1 <--- PB1 & .210 & .080 & 2.624 & .009 & $\mathrm{H}_{3}$ is accepted \\
\hline AB1 <--- BI1 & .534 & .096 & 5.572 & $* * *$ & $\mathrm{H}_{4}$ is accepted \\
\hline AB1 <--- PB1 & .377 & .082 & 4.593 & $* * *$ & $\mathrm{H}_{5}$ is accepted \\
\hline
\end{tabular}

Of the three variables that determine the investing intention, namely attitudes toward investment (AT1), subjective norms in investing (SN1) and perceived behavioral control in investing (PB1), only variable subjective norms in investing (SN1) has no effect on the investing intention of the novice investors before the Covid-19 Pandemic (its probability value is 0.693> 0.05). Furthermore, investing intention (BI) influences investing behavior (AB) with a probability value of less than 0.001 (***). Meanwhile, perceived behavioral control in investing (PB1) also has a positive and significant direct effect on the investing behavior of novice investors.

Table 5 shows the results of the analysis of the behavior of novice investors during the Covid-19 Pandemic. It appears that all independent variables, namely attitudes towards investment (AT2), subjective norms in investing (SN2) and perceived behavioral control in investing (PB2), have a positive and significant effect on the investing intention of novice investors (probability value $<0.05$ ). Then, investing intention (BI2) also has a positive and significant effect on investing behavior (AB2) with a probability value of less than 0.05 . 
Likewise, perceived behavioral control in investing (PB2) has had a positive and significant direct effect on investing behavior (AB2) during the Covid-19 Pandemic.

Table 5. Regression Weight - During Covid-19 Pandemic

\begin{tabular}{|c|c|c|c|c|c|}
\hline & Estimate & S.E. & C.R. & $\bar{P}$ & Result \\
\hline BI2 <--- AT2 & .448 & .068 & 6.576 & $* * *$ & $\mathrm{H}_{1}$ is accepted \\
\hline BI2 <--- SN2 & .113 & .056 & 2.021 & .043 & $\mathrm{H}_{2}$ is accepted \\
\hline $\mathrm{BI} 2<---\mathrm{PB} 2$ & .341 & .086 & 3.981 & $* * *$ & $\mathrm{H}_{3}$ is accepted \\
\hline $\mathrm{AB} 2<---\mathrm{BI} 2$ & .852 & .101 & 8.474 & $* * *$ & $\mathrm{H}_{4}$ is accepted \\
\hline AB2 <--- PB2 & .185 & .092 & 2.010 & .044 & $\mathrm{H}_{5}$ is accepted \\
\hline
\end{tabular}

From Table 4 and Table 5 showthat novice investors have almost the same behavior in both periods, before and during the Covid-19 Pandemic. The only difference is the influence of the subjective norm on investing intention. In the pre-pandemic period, this factor had no effect on investing intention. Meanwhile, during a pandemic, this factor has a positive and significant effect.

In general, it can be said that the behavior of novice investors in investing was in accordance with was stated in Ajzen's planned behavior theory, both before the pandemic and during the pandemic. Investment intention is influenced by attitudes towards investment, and perceived behavioral control of investment. However, what was different from the theory of planned behavior was that before the pandemic, the factor of subjective norm in investing did not affect the intention of novice investors to invest. Meanwhile, during a pandemic, this factor has a significant effect on investment intentions, as stated in the theory of planned behavior.

\section{Discussion}

This study is an implementation of a theory of planned behavior in a group of novice investors for two events, namely before the Covid-19 Pandemic and during the pandemic. Both before the Covid-19 Pandemic and during the Covid-19 Pandemic, the investment activities of novice investors on the Indonesia Stock Exchange were influenced by attitude toward investment. This is in line with the results of research conducted by Pahlevi \& Octaviani (2018), in which the attitude toward behavior has a positive influence on the individual investor intentions on investment in Indonesia Stock Exchange. The same result was also stated by Ejigu \& Filatie (2020), where attitude and perceived behavioral control were significant in affecting the business students' intention to invest in Micro and Small Enterprise in Ethiopia. Meanwhile, 
Mahastanti \& Hariady (2014) in their research concluded that attitude to behavior and subjective norms did not affect the intention to buy financial products.

Subjective norm in investing has a different effect on the behavior of novice investors. Prior to the Covid-19 pandemic, subjective norm had no effect on investing intention of investors. This is in line with the results of the research by Listyarti \& Suryani (2014) which concluded that subjective norms have no effect on investment intentions in the Indonesian capital market. Ejigu \& Filatie (2020) from the results of their research also conclude the same thing, namely subjective norms was not statistically significant in affecting intention though it has a negative relationship with the intention to invest. Mahastanti \& Hariady (2014) also conclude that subjective norms have no effect on the intention to buy financial products in the Indonesian capital market.

The non-effect of subjective norms on investors' investment intentions may be due to the fact that in the days before the Covid-19 Pandemic, where the economy was in normal condition and the opportunity to invest was very wide, novice investors found it easy to invest, even though they lacked experience and relied more on intuition than theory. . In such situations, they are also more courageous in taking risks, with consideration that if they fail they feel they can try again to achieve success. This can be done by novice investors, given the normal economic situation and conditions, without turmoil and there are opportunities for better development.

But the opposite happened during the Covid-19 Pandemic, investors tended to act more cautiously, were more conservative and tended to consider the risks that might occur. In addition, at this time, in making decisions, novice investors tend to consider all information and learn from the experiences of other more experienced investors. They also pay more attention to recommendations, information and advice from fellow investors rather than based on personal intuition. The more influential outsiders or recommendations from others, the more influence the investment decisions made by investors (Listyarti \& Suryani, 2014). This is what makes subjective norms have a positive influence on investment intention, as stated by Rahadjeng\&Fiandari(2020), Pahlevi\& Oktaviani(2018), Listyarti \& Suryani (2014) and Seni \& Ratnadi (2017).

The results of research by Rahadjeng\& Fiandari (2020) show that attitude, subjective norms and behavioral control have an influence on the intention to invest in share investment. This is in line with the research results of Pahlevi \& Oktaviani (2018), Listyarti \& Suryani (2014) and Seni \& Ratnadi (2017) which concluded that the attitude, subjective norm, perception of behavior control, have positive effect on investors' intention in investing. 
Perceived behavioral control affects investors' intention to invest, both before the Covid19 Pandemic and during the pandemic. This is in line with the results of research conducted by Ejigu \& Falatie (2020), Njuguna, Namusonge,\& Kanali (2016), and Mahastanti \& Hariady (2014), which concluded that perceived behavioral control has a positive effect on behavioral intention.

Investing intention has had a positive and significant influence on investing behavior, both before the Covid-19 Pandemic and during the pandemic. This is in line with the results of research conducted by Paramita, et al. (2018) and Mahardhika\& Zakiyah (2020) and concluding that investment intention has a positive effect on millennial investors' actual behavior in investing in stocks.

\section{E. Conclusion}

Based on the inferential analysis in can be concluded that there is no different impact of attitude towards investment and perceived behavioral control in investing toward investing intention before and during Covid-19 Pandemic. Those two variables have significant influence on investing intention. Either does the impact of investing intention towards investing behavior. Investing intention influences investing behavior both in the era before and during pandemic. The only difference is about the impact of subjective norm in investing towards investing intention. Before pandemic, subjective norm in investing does not influence investing intention. Meanwhile, during pandemic subjective norm in investing influences investing intention.

This research result shows that a Covid-19 Pandemic changes the investing intention of novice investor in Indonesia through subjective norm in investing. It can be explained that during the pandemic, the novice investor in Indonesia are more prudent when investing their money in Indonesia Stock Exchange. Others' decision influences their investing intention during pandemic.

This research result encourages the stock market authority to share positive information about stock market and its activities. Positive information will increase an investing intention, and negative information will decrease an investing intention. So, a good information management skill is very needed. 


\section{References}

Agustina, M. 2013. Siap-siap 1 Lot Saham Berubah pada 6 Januari 2014. https://www.liputan6.com/saham/read/782482/siap-siap-1-lot-saham-berubah-pada-6januari-2014

Ajzen, I. (2005). Attitudes, Personality and Behavior. New York. USA: Open University Press.

Ajzen, I. 1991. The Theory of Planned Behavior. Organizational Behavior and Human Decision Processes, 50, 179-211.

Ajzen, I., \& Fishbein, M. (1980). Understanding attitudes and predicting social behavior. Englewood Cliffs, NJ: Prentice Hall.

Alalwan, A.A., Dwivedi, Y.K., \& Rana, N.P. (2017). Factors influencing adoption of mobile banking by Jordanian bank customers: Extending UTAUT2 with trust. International Journal of Information Management, 37(3), 99-110.

https://doi.org/10.1016/j.ijinfomgt.2017.01.002

Bursa Efek Indonesia. 2017. Yuk Nabung Saham. http://yuknabungsaham.idx.co.id/about-yns

Dow, J.P. (2018). Attitudes towards credit after the Great Recession. Applied Economics Letters, 25(4), 254-257. https://doi.org/10.1080/13504851.2017.1316817

Ejigu, S.N.\&Filatie, Y.S. 2020. Determinants of Investment Intention in Micro and Small Enterprises Among Business College Students in East Gojjam Zone. Research Journal of Finance and Accounting, 11(3).

Foltz, C.B., Newkirk, H.E., \& Schwager, P.H. (2017). An Empirical Investigation of Factors that Influence Individual Behavior toward Changing Social Networking Security Settings. Journal of Theoretical and Applied Electronic Commerce Research, 11(2), 1-15. https://doi.org/http://dx.doi.org/10.4067/S0718-18762016000200002

Ghozali, I. 2011. Model Persamaan Struktural. Konsep dan Aplikasi dengan Program Amos 21.0. Semarang: Badan Penerbit Universitas Diponegoro.

Hoffmann, A.O.I., Post,T., \& Pennings, J.M.E. (2013). Individual investor perceptions and behavior during the financial crisis. Journal of Banking and Finance, 37(1), 60-74. https://doi.org/10.1016/j.jbankfin.2012.08.007

Hutauruk, D.M. 2021. Jumlah Investor Meningkat tapi Pasar Modal Masih Kekurangan Analis Kompeten. https://investasi.kontan.co.id/news/jumlah-investor-meningkat-tapi-pasar-modal masih-kekurangan-analis-kompeten

Ibrahim, Y.\& Arshad, I. (2017). Examining the impact of product involvement, subjective norm and perceived behavioral control on investment intentions of individual investors in Pakistan. Investment Management and Financial Innovations, 14(4), 181-193. https://doi.org/10.21511/imfi.14(4).2017.15

Kashif, M., Zarkada, A., \& Ramayah, T. (2018). The impact of attitude, subjective norms, and 
perceived behavioural control on managers' intentions to behave ethically. Total Quality Management and Business Excellence, 29(5-6), 481-501.

https://doi.org/10.1080/14783363.2016.1209970

Listyarti, I. \&Suryani, T. 2014. Determinant factors of investors' behavior in investment decision in Indonesian capital markets. Journal of Economics, Business, and Accountancy Ventura, 17(1), $45-54$. https://www.researchgate.net/publication/284597630_Determinant_factors_of_investors

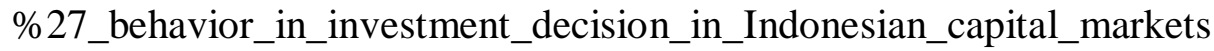

Mahardhika, A.S. \& Zakiyah, T. 2020. Millennials' Intention in Stock Investment: Extended Theory of Planned Behavior. JURNAL Riset Akuntansi dan Keuangan Indonesia, 5(1). file:///D:/PRES-UNIV/JOURNAL/NOVICE\%20INVESTOR\%20 BEHAVIOR/ Millennials\%20Intention\%20in\%20Stock\%20Investment.pdf

Mahastanti, L. \& Hariady, E. 2014. Determining the factors which affect the stock investment decisions of potential female investors in Indoensia. International Journal of Prosecc Management \& Benchmarking, 4(2), 186-197.

Mahyarni. 2013. Theory Of Reasoned Action Dan Theory of Planned Behavior (Sebuah Kajian Historis tentang Perilaku). Jurnal El-Risayah, 4(1), 17.

https://www.neliti.com/publications/244719/theory-of-reasoned-action-dan-theory-ofplanned-behavior-sebuah-kajian-historis

Njuguna, P.K., Namusonge, G.S, \& Kanali, C. 2016. Determinants of Investment Intentions: An Individual Retail Investor's Perspective from Nairobi Securities Exchange. International Journal of Arts and Commerce, 5(6).

Olavia, L. 2021. Kepercayaan Investor Pemula terhadap Pasar Modal Harus Dijaga. https://www.beritasatu.com/ekonomi/726311/kepercayaan-investor-pemula-terhadap-pasarmodal-harus-dijaga

Pahlevi, R.W. \&Oktaviani, I.I.2018. Determinants of Individual Investor Behaviour in Stock Investment Decisions. AFRE Accounting and Financial Review, 1(2): 53-61. File:///D:/PRES-UNIV/JOURNAL/NOVICE\%20INVESTOR\%20BEHAVIOR/ Determinants\%20of\%20Individual\%20Investor\%20Behaviour\%20in\%20Stock\%20Invest ment $\% 20$ Decision.pdf

Palamida, E., Papagiannidis, S., \& Xanthopoulou, D. (2017). Linking young individuals' capital to investment intentions: Comparing two cultural backgrounds. European Management Journal, 36(3), 392-407. https://doi.org/10.1016/j.emj.2017.06.004.

Paramita, R.S., Isbanah, Y., Kusumaningrum, T.M., Musdholifah, M., \& Hartono, U. (2018). Young investor behavior: implementation theory of planned behavior. International Journal of Civil Engineering and Technology, 9(7), 733-746. https://www.researchgate.net/publication/327335452

Rahadjeng, E.R. \& Fiandari, Y.R. (2020). The Effect of Attitude, Subjective Norms and Control of Behavior towards Intention in Share Investment. Manajemen Bisnis, 10(2), 17-25. 
file:///D:/PRES-

UNIV/JOURNAL/NOVICE\%20INVESTOR\%20BEHAVIOR/THE\%20EFFECT\%20OF $\%$ 20ATTITUDE\%20ETC\%20TOWARD\%20

INTENTION\%20IN\%20SHARE\%20INVESTMENT.pdf

Raut, R.K., \& Das, N. (2017). Individual investors' attitude towards online stock trading: some evidence from a developing country Rajdeep Kumar Raut * and Niladri Das. Int. J. Economics and Business Research, 14, 254-267. https://doi.org/10.1504/IJEBR.2017.087495

Ruiz-Rosa, I., Gutiérrez-Taño, D., \& García-Rodríguez, F. J. (2020). Social entrepreneurial intention and the impact of COVID-19 pandemic: A structural model. Sustainability (Switzerland), 12(17), 9-12. https://doi.org/10.3390/SU12176970.

Santoso, S. 2012a. Analisis SEM Menggunakan Amos. Jakarta: PT Elex Media Komputindo.

Santoso, S. 2012b. Aplikasi SPSS pada Statistik Multivariat. Jakarta: PT Elex Media Komputindo.

Seni, N.N.A.\&Ratnadi, N.M.D.. 2017. Theory of Planned Behavior untuk Memprediksi Niat Berinvestasi. E-Jurnal Ekonomi dan Bisnis Universitas Udayana, 6(12).

Sidik, S. 2020. Ini Fakta Investor Ritel Jadi Penguasa Bursa Saham RI. https://www.cnbcindonesia.com/investment/20201214123723-21-208901/ini-faktainvestor-ritejadi-penguasa-bursa-saham-ri

Taufiqoh, E., Nur, D., \& Junaidi. (2019). Pengaruh Norma Subjektif, Motivasi Investasi, Pengetahuan Investasi, Persepsi Return dan Literasi Keuangan Terhadap Minat Mahasiswa Berinvestasi Saham di Pasar Modal. E-Jra, 08(05), 1-13. http://riset.unisma.ac.id/index.php/jra/article/view/4063

Trang, P. T. M., \& Tho, N. H. (2017). Perceived Risk, Investment Performance and Intentions in Emerging Stock Markets. International Journal of Economics and Financial Issues, 7(1), 269-278. Available at: https://www.researchgate.net/publication/312369320.

Yuniningsih, Y., \& Taufiq, M. (2019). Investor Behavior in Determining Investment on Real Asset. Mix: Jurnal Ilmiah Manajemen, 9(2), 327.

https://doi.org/10.22441/mix.2019.v9i2.006 